\title{
Developing Ethic Game (Ethnomathematics Game): The Instructional Media of Culture Mathematics with Tringo by Ki Hadjar Dewantara
}

\author{
Sayyidati Fatimah Az-Zahroh, Zahid Zufar At Thaariq, Ence Surahman, Chania M. Widyasari, \\ Muhammad Syifa'ul Qolbi, Risma Chulashotud Diana \\ Universitas Negeri Malang
}

\begin{abstract}
One of the most important steps in having educational process with the media. The media itself represents the component of Language Leaning. In researchers' context, which is Math, the subject matter represents the content itself. Most of the times, our students face difficulty in learning the content-Math subject. Therefore, the objective of this study is to produce an instructional media that might ease the students in learning Mathematics easier and meaningful. Our interest is developing an instructional media that help students to also learn culture as its additional material. We develop ETHIC GAME (Ethnomathematics Game) as an integrated and augmented reality-based (AR) instructional media that combine mathematics and culture. Based on Edgar Dale's theory on learning, the students can undergo the meaningful learning experience when they learn, observe, and listen to the media by themselves. We decide then to make an instructional media that also use such kind of principle that is TRINGO (Ngerti, Ngrasa, Nglakoni - or Understanding, Experiencing, Doing) by Ki Hadjar Dewantara. The development method used in this study refers to Lee Owen model of development. In the end, by having ETHIC GAME as instructional media, students learn more insightful and meaningful Mathmatics and culture - not only to make the learning process more authentic, but also to make the learners preserve the national culture. Indicates how easy the users in using the application which shows $100 \%$ of the users stated that there is no difficulty in using it. So, this instructional media can be used easily and fun.
\end{abstract}

Keywords: Augmented Reality, Board Game, Ethnomathematics, Instructional Media, Principle of TRINGO.

Indonesia has been known for its richness, both in the aspect of nature or its culture. As an archipelago country, Indonesia has 250 tribes and languages that have hundreds of historical inheritances in the form of temples, museums, forts, caves and many more (PDSPK Kemendikbut RI, 2016). Edi Sedyawati (1994:8) stated that cultural inheritances keeps on growing from the development of certain culture in every regionwhich brings impact in shaping the characteristics of their own people (Manuaba, 1999). However, as globalization occurs, to preserve culture will not be easy because it brings effects to our daily life. For example, the western culture can change people behavior, especially the young generation-which are mostly students. They will follow the trends in any aspects, starting from what they wear: fashion and beauty to what they hear and enjoy: music. The ironical issue from this modernization is that our students know more the Western culture, such as breakdance, hip-hop dance, EDM (western) music rather than traditional arts. Thus, it is important to find any ways that might help young generation to preserve and converse the national culture.

Other than that, the young generation of Indonesia also face other problem: the lack of interest in studying mathematics. A study shows taht $70 \%$ of students in elelmentary level dislike their Math subject because the material and learning method seem to be unappealing since the teachers are still using the old-way of teaching (Faisal, 2016; Santika, 2019). Students are tend to get used to such conditions of learning - they become passive - in which the teachers dominate the class by explaining the materials. (Nurrahmawati, 2016; Himmatul dan 
Ratri, 2017). According to Programme for International Students Assessment (PISA) data, Indonesia rank the $63^{\text {rd }}$ position out of 70 other countries in mathematics and numeracy literacy (Siregar, 2017). Thus, we can conclude that Indonesian people still have low interest in studying Mathematics, and therefore there should be a way to shift it.

According to Indonesian's Regulation No. 20 year 2013 on the chapter of National Education System, the aim of national education is to develop numeracy skills to and for people. It indicates the importance of learning mathematics since the early age. One of the way is to learn it from the very basic level and perhaps using various instructional media or other topic that might be relevant and authentic. For that reason, the researchers think that ethnomathematics can be applied in this condition because all the mathematics topic will be linked to the learners' culture (Rakhmawati, 2016).

Linking or integrating Math subject to other discipline, such as culture, will help the learners to learn better. In such case, we call it as ethnomathematics. It is one of applied mathematics field where we use the values of culture or local wisdom to study mathematics itself (Jati, Mastur \& Asikin, 2019). By applying the concept of ethnomathematics, it does not mean that the materials will be limited. In fact, it brings broader concept of mathematics, such as: categorizing, calculating, measuring, designing plane figures, and still a lot more (Komala, Santana, \& Hendriana, 2019). In short, we relate what we have in mathematics to what we have in our culture. By doing so, it eases the learners to understand the concepts of mathematics and - at the same timeenrich their cultural insight, so they will not get bored in the process of teaching nad learning mathematics (Wahyuni, Tias, \& Sani, 2019).

Related to previous discussion about ethnomathematics, one more thing that should come into consideration is the media itself. As stated in the beginning that we have come to the era of globalization, it is important to also link what we want to have in our classroom with technology. In today's era, one of the commonly used technology in classroom setting are Augmented Reality (AR) and mobile-assisted learning. AR refers to a system or technology that brings virtual object from computer to the real-life dimension (Wicaksono, Ardianto, \& Erandaru, 2019). Other terminology explains that AR is taken from English and translated as additional reality (Soepriyatno, \& Rahmatullah, 2017). It can be concluded that AR merge virtual object and its surrounding in two dimensional or three dimensional. Moreover, to merge it effectively all we need are compactible devices, the interactivity from it, and of course integrated and continuum trial (Falaq, Thaariq, \& Afanililah, 2019).

Other technology that previously mentioned is mobile-assisted learning as the technology in our classroom. The basic point that should be highlighted from it is that, it mainly does what learning process do in the classroom; but, it should be integrated to the use of mobile devices. Cobcroft states the criteria for a device that can be used as a tool of mobile-assisted learning; it should: motivate the learners to have lifelong learning, flexible to the learners in terms of mobility, for personal use in connection to technology, and it should conduct a student-centered kind of learning (Surahman \& Surjono, 2017). As an innovation of learning methodology, mobile-assisted learning appears as a flexible alternative of learning process in which the students can conduct their own learning process. It means that they do not need to come to the class or laboratory. In fact, they will have more studentcentered learning process rather than the conventional way, teacher-centered (Surahman, 2019).

Although the integration of technology in learning process - in this term: AR and mobileassisted learning - brings effectiveness in todays' classroom, still it is also important to input the elements of students' interactivity on it. The appropriate approach in our situation today is cooperative learning. Cooperative learning is one kind of learning approaches in which all technical steps should be done in a group (Vonny, Mawa'Ratu, \& Tambunan, 2019). It emphasizes the team work from each member on its implementation (Thaariq, Alfia, \& Kusworo, 2018). The purpose, of course, is to make up the teaching and learning process becomes more active among teacher and students. 
One of the parts of cooperative learning approach is the principle that we rarely study this time: TRINGO (Ngerti, Ngrasa, and Nglakoni). This concept shows that there is an art even in a cooperative learning, although it can't be seen easily. It involves three main substantial points: ngerti or understanding, ngrasa or experiencing, and nglakoni or doing. Thus, the learners need to see their learning process should start with a good understanding. It build their feeling to face the next steps that they will do in their learning process by experiencing the things in the group; and the last, they can implement or apply or do something in their real-life short after (Kuswandi et al., 2018). TRINGO principle is taken from $\mathrm{Ki}$ Hadjar Dewantara's concept in learning. It has been developed in many kinds of learning components although in fact, it is an old-established principle. However, if we want to take a look to its components closer we can see that it is still applicable to this era in which we can develop or use it as learning model, learning reference, learning strategy and many more (Diana, Kuswandi, \& Ulfa, 2019).

Based on explanation given, researchers would like to develop an instructional media that cover ethnomathematics and apply TRINGO as its main principle along with the implementation of technology. As a result, we decide to make an instructional media entitled ETHIC GAME that stands for ETHnomathematIC GAME. By having a learning-with-fun method, we do expect that ETHIC will enrich students' cultural insight and increase their interest in studying Mathematics. The target user of this game is elementary learners as how Hurlock, Istiwidayanti, Sijabat, \& Soejarwo (1990) agreed that they should learn something through game to make their learning more meaningful and memorable.

\section{METHOD}

In this study, the researchers use Research and Development (R\&D) method and quantitative approach. The researchers adapt Lee Owen's research procedures that consist of analyzing, designing, developing, implementing, and evaluatin ( Lee \& Owens, 2004). For the first step which is analyzing, researchers conduct a Needs Analysis or Needs Assessment (NA) by reviewing literature. It then continues by designing the media and developing it until it is ready for use. The implementation itself should be done as the first trial of ETHIC. After all steps are done, the result shows several things: users' interest, users' increase point of cognitive-affective-psychomotor, and some other points related to users' testimony.

During the analysis, researcher conduct a review of related literature. We focus on finding the relevant studies that can be citated or studied for this writing. Some issues that we try to find are general problems or challenges and its solutions that might be occurred. As our considerations, we decide to use books, journals, writers' note and still some more.

After finish analyzing the literature, we design the media by using the principles of design and the principles of multimedia. One of them is interface as the principle of design that refers to heuristic evaluation that consists of visibility of system status (feedback), mattch between system and the real world (metaphor), User control and freedom (navigation), Consistency and standards (consistency), Error prevention (prevention), Recognition rather than recall (memory), Flexibility and efficiency of use (efficiency), Aesthetic and minimalist desain (desain), Help users recognize, diagnose, and recovers from errors (recovery) dan Help and documentation (help) (Caesaron, 2015). In other side, for the principles of multimedia, we use Mayer's that consists of (1) Coherence principle, (2) Redundancy principle, (3) Sign principle, (4) Temporary Connection principle, (5) Distribution principle, (6) Deviation principle, (7) Pre-training principle, (8) Modality principle, (9) Multimedia principle, and the last (10) Personalization principle (Mayer, 2002).

On the next stage, researchers develop the media - in this occasion, it is in form of the game. It involves the creativity, idea, and energy that cost priceless experience; and should results the visible product (Alwi, 2017). The development starts from video making and $3 \mathrm{D}$ animation construction. Then, it is connected to Unity and Vuvoria, and ends with the validation by experts. Here, we use 2 kinds of expert: media expert and material expert.

After having some steps to do, it comes to the end where the stage is implementation as the first trial of ETHIC Game. The trial or try-out is done to 
the students of elementary level by following the learning and teaching process as how it is supposed to be. They consist of 40 children under the age of $10-12$ years old in the grade $4^{\text {th }}$ to $6^{\text {th }}$ of elementary school.

\section{RESULT AND FINDING}

This study produces an instructional media that has been implemented. The result of its try-out can be seen in the diagram below.

The resulted data explains the opinion of ETHIC GAME users after the try-out. Item (1) indicates how easy the users in using the application which shows $100 \%$ of the users stated that there is no difficulty in using it. Item (2) indicates how meaningful and fun the learning process is when they use ETHIC GAME. At least, 50\% users said "YES", $40 \%$ of them said "NEUTRAL", and 10\% of them said "NO". The item (3) indicates that ETHIC GAME contains insightful cultural value on it.

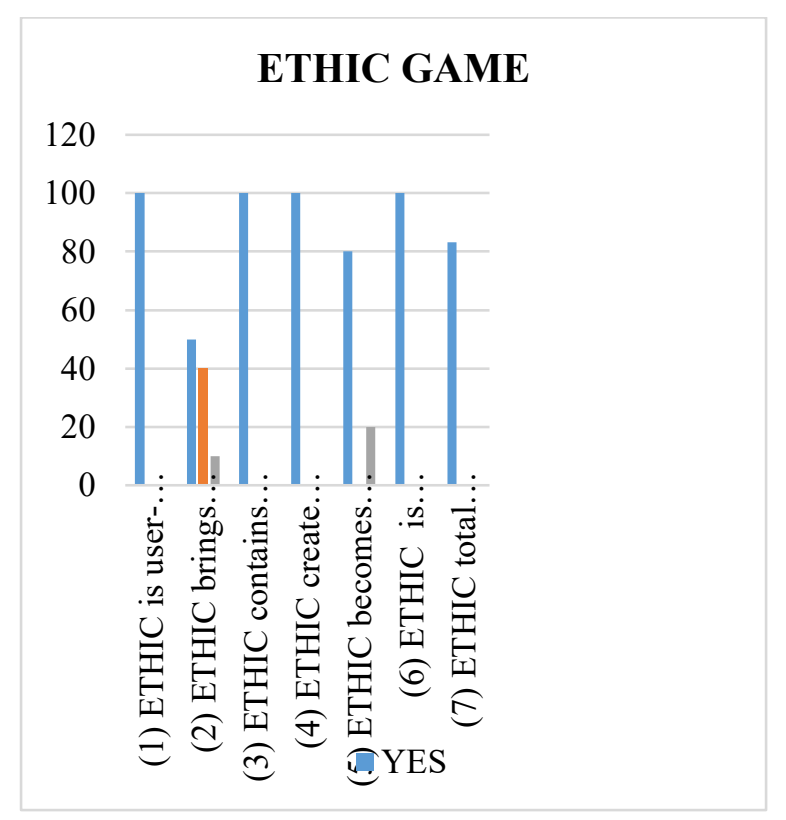

Picture 1. The result starts from 08.00-10.30.

The gained data from trying out the media that contains several items to answer by the students/colleagues.

The users said $100 \%$ agree to say that their knowledge about culture increase. Item (4) indicates how ETHIC GAME crate cultural awareness to their users beause $100 \%$ of the users said "YES" for it. Next, item (5) indicates how good ETHIC GAME as a product that help children to preserve their culture. The result shows $80 \%$ of the users say YES that it helps, and $20 \%$ say NO. Then item (6) talks about its interest for the users. It shows a surpring result in which it shows $100 \%$ of them are interested in using ETHIC CAME. The last item, which is item (7) shows the total score that users give to ETHIC GAME as they finished playing. For this part, $80 \%$ of users said YES which means ETHIC GAME can be considered as an appropriate instructional media.

\section{DISCUSSION}

ETHIC GAME is an instructional media that cover ethnomathematics topic for learners of elementary level, to be exact the $4^{\text {th }}$ up to $6^{\text {th }}$ graders. It aims to help the young generation in preserving the national culture, and to increase their motivation in learning Mathematics. The given solution was made based on some regulations, such as:

a. Indonesia Regulation no. 5 year 2017 about Culture Advancement.

b. Subsection 32 of 1945 State Constituent of the Republic Indonesia about Nation Support in National Culture Advancement.

c. Indonesia Regulation no.20 year 2003 about National Education System.

On its main concept, ETHIC GAME contains ethnomathematical topic that cover culture of Indonesia and focus on plane figures, solid figures, arithmetic, and rotation as mathematic topics. It uses TRINGO approach that introduced by Ki Hajar Dewantara, The Educational Father of Indonesia. TRINGO consists of Ngerti, Ngrasa and Nglakoni (Understanding, Experiencing and Doing). This kind of approach is suitable to students' learning process and helpful for them to achieve the learning objectives (Kuswandi, Surahman, Thaariq, and Muthmainnah, 2019).

Through this game, the learners will implement TRINGO process in one. The process of $\mathrm{Ngerti} /$ Understanding can be seen by students understanding of the concepts of the game. The process of Ngrasa/Experiencing can be seen by collaborative learning done that 
affect learners' social interaction. Last, the process of Nglakoni/Doing can be seen from students' activity in answering the given challenges or questions.

ETHIC GAME appears as a board game that has several components:

\section{a. Board Game}

The board consists of 'starting point' and 'finish point'. There are maximum 6 students who can play this game in a round. Board game as a container in the play or base used. Playing board games may promote foundational number skills through helping children learn to accurately map numbers to space; a critical skill, underlying a breadth of mathematical tasks (Hawes et al., 2019). For example, board games including strategy games, family games, battle games, and puzzle games have received more and more attention in the past few years (Tseng, Yang, \& Lu, 2019).

b. Cards

The cards of ETHIC GAME consist of'question card', 'challenge card', 'do you know? card' and 'power card'. The card game comprising a plurality of sets of location cards, one set of location cards for each of a plurality of locations asso ciated with an aspect (Shideler \& Shideler, 2017)

\section{c. Pawns}

There are several pawns on the game that represent the total number of players.

\section{d. Dice}

It helps the player to know how many steps they have and in which counter will they stop. This dice is unique because it uses a number calculation in it.

\section{e. Mobile Phone}

Mobile phone will help the learners to display the Augmented Reality (AR) animation. It can be traditional dances, songs, and many more.
As in instructional media, there are some steps to do based Wrihatnolo \& Dwidjowijoto (2007) theory in teaching and learning process for young age. Some steps to be considered are listed down below.

a. Sensible. Learners will receive a lecture evoke their sense of awareness on cultureincludes its importance and values.

b. Enable. Learners will learn how to use the game and how to learn through it. Moreover, the explanation will also be given to the parents and teachers as their support system.

c. Empowerment. Learners will have their own authority and chance to be better in learning. In this step too, the researcher will focus on empowering students' interest of preserving the culture by the free of charge ETHIC GAME.

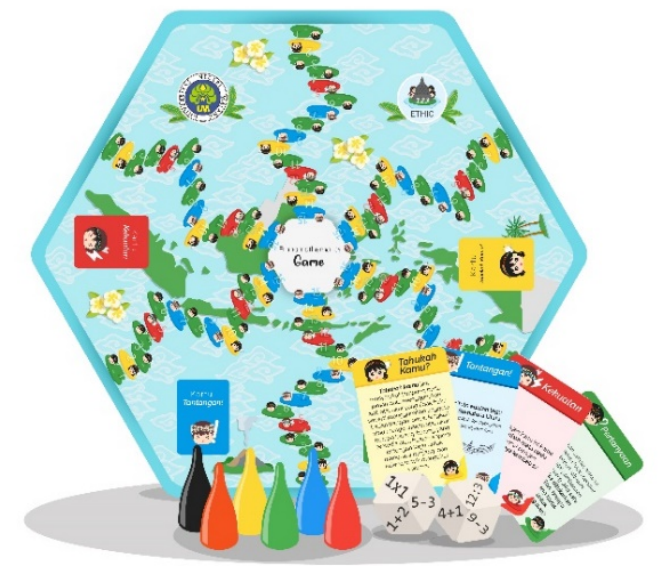

Figure 2. ETHIC GAME Components.

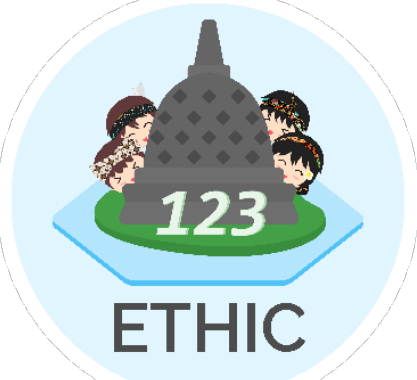

Figure 3. Logo ETHIC GAME.

To make ETHIC game come into realization in preserving Indonesian culture and improving 
mathematics literacy, the researchers do need some parties to be involved:

a. The Ministry of Education and Culture

b. Play role as someone who give permission in more an ease way, especially when it comes to the administration.

c. Media Developer

d. To play important roles in in making various elements of the media.

e. School

f. As the school counts well, they have to prepare several documents.

g. The expert of material

h. Just to check and recheck all the materials that is being put on the media.

i. The expert of media

j. In order to validate the instructional media that has been made, the researchers really need to have an expert in media.

On its concept, ETHICS Game itself is using The Cone of Experiences by Edgar Dale. This theory explains how someone's learning experiences and concrete or abstract concept (Suswina, 2016). It makes the students can learn in the future, while later on, you ask them to walk it one-by-one. This theory helps the researcher or many other scholars to shape learning experiences among their learners (Mahnun, 2012). As you can see in the diagram below, there are some interesting points. The top of the cone does not represent that the sharper it is the more complicated or abstract the materials are. We begin our journey to find the learning experience by having group of students studying together about the given solution.

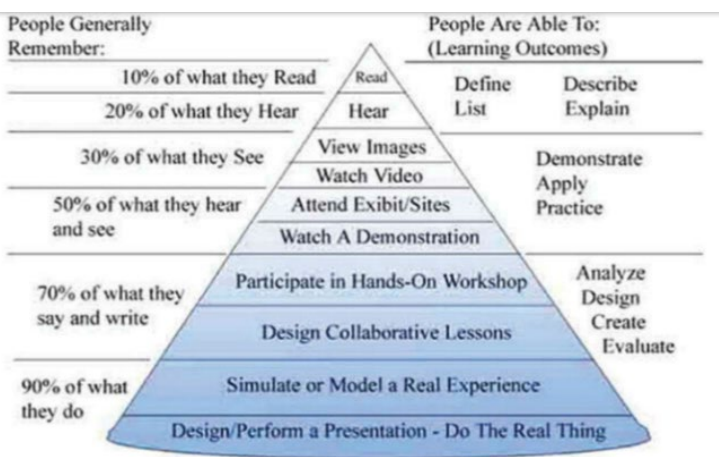

Figure 4. Edgar Dale's Cone of Experience
If we take a closer look into the cone, ETHIC Game actually provides a step-by-step learning process. It starts from the way of concrete learning until how abstract it is. It gives a positive impact to learner's cognitive development. Implicitly, we bring the learner to enjoy their learning process by playing or having fun.

Related to the use of board game in our instructional media, there are numerous studies have been conducted about it. Tangidy \& Setiaran (2016) studied about board game and its use in pela gandong. The result shows at least $90.57 \%$ of the users agree that they can play pela gandong easily while understanding the social pattern in our society. Moreover, there are still other result from it: (1) $89.71 \%$ of respondents strongly agree that board game help them to learn pela gandong as a culture easily, and (2) $89.14 \%$ of respondents strongly agree that the instruction given is suitable to the media itself.

Other than that, there is still another study that has been conducted about the use of board game and mathematics. The study was conducted by Fathurrohman, Nindiasari, \& Rahayu (2016) to prove the same thing. By using qualitative approach, this study tries to discover the effectiveness of board game through interviewing the respondents. The outcome is then students' opinion that students' feel interested and enjoy the learning process through board games. Even they can repeat the games for several times.

Based on the previous studies existing, the researchers think that the production of ETHIC can strengthen the same result in instructional media. This because ETHIC accommodates learners' cognitive development and intelligence. Such kind of intelligence is usually known as multiple intelligence that involves visual-spatial, music, language, mathematic, kinesthetic, interpersonal, intrapersonal, dan natural (Gardner, 1992). At least those points give us a general draw of what teachers actually need on their teaching process. Later, teacher might want to adjust it based on students' needs that follow criteria of (1) Products or services supplied (2) Level of authority or scope of operations overseen dan (3) Nature of responsibilities (Martin, 2018) 
Although all individual might have 8 kinds of intelligence, it does not mean that they can have them all in once with the same level. Each person has different level of intelligence. Several reaches think that it is unnecessary to create a fascinating learning activity in the classroom. On the other hand, we know that by such decision, teachers cannot facilitate language development or any kind of other verbal intelligence (Baş \& Beyhab, 2017). While actually, there is one way to do it by rethinking learning activity that can be used frequently in the classroom and categorized it based on different kind of intelligence (LarsenFreeman, 2000).

\section{CONCLUSION}

As the impact of globalization, Indonesian young generation today facing some problems in numeracy literacy in Mathematics and cultural problems. It is necessary for scholar to create something with the purpose of solving those problems. In this study, researchers generate an instructional media called ETHIC GAME that use ethnomathematics concept and TRINGO principle on it. On its main concept, ETHIC GAME contains ethnomathematical topic that cover culture of Indonesia and focus on plane figures, solid figures, arithmetic, and rotation as mathematic topics. It uses TRINGO approach that introduced by Ki Hajar Dewantara, The Educational Father of Indonesia. TRINGO consists of Ngerti, Ngrasa and Nglakoni (Understanding, Experiencing and Doing). Our main target user are learners in the age of elementary levels, especially $4^{\text {th }}$ to $6^{\text {th }}$ graders. Researchers do expect that several parties - such as: Ministry of Education and Culture, media developer, and many more-involved to bring this positive impact to our people. By then, we can introduce this ethnomathematics to greater number of students.

\section{REFERENCES}

Baş, G., \& Beyhab, Ö. (2017). Effects of multiple intelligences supported project-based learning on students' achievement levels and attitudes towards English lesson. International Electronic Journal of Elementary Education, 2(3), 365386.
Caesaron, D. (2015). Evaluasi heuristic desain antar muka (interface) Portal mahasiswa (studi kasus portal Mahasiswa universitas x). Jurnal Metris, $16(1), 9-14$.

Faisal, F. (2016). Upaya Meningkatkan Prestasi Belajar Matematika Siswa di SDN Cepit dengan Menggunakan Media Benda Kongkrit. BASIC EDUCATION, 5(5), 442-448.

Falaq, F. I., Thaariq, Z. Z. A., \& Afanililah, M. H. (2019). Pengembangan I-QURAN (Inclusive Quran) sebagai Media Pembelajaran Al Qur'an Berbasis Augmented Reality untuk Penyandang Disabilitas. I-JET: Indonesian Journal of Educational Technology, 1(1), 1-14.

Fathurrohman, M., Nindiasari, H., \& Rahayu, I. (2016). Pengembangan Board Game Matematika Di SD Negeri Wadasari Kabupaten Serang. Eprints UNY, 465-472.

Gardner, H. (1992). Multiple intelligences (Vol. 5). Minnesota Center for Arts Education.

Hawes, Z., Cain, M., Jones, S., Thomson, N., Bailey, C., Seo, J., ... Moss, J. (2019). Effects of a TeacherDesigned and Teacher-Led Numerical Board Game Intervention: A Randomized Controlled Study with 4-to 6-Year-Olds. Mind, Brain, and Education.

Kuswandi, D., Surahman, E., Wedi, A., Ulfa, S., Sulthoni, Thaariq, Z. Z. A., \& Diana, R. C. (2018). Pengembangan Adaptive Learning Analytics Management System(Alams) Berbasis Synchronous Dan Asynchronous Learning Dan Berlandaskan Konsep Belajar Tringo (Ngerti, Ngrasa, Ngelakoni) Dari Ki Hadjar Dewantara Untuk Membangun Smart Online Learning Environment (Sole) Di Jurusan Teknologi Pendidikan. Malang: Inobel UM.

Larsen-Freeman, D. (2000). Techniques and principles of language teaching. Oxford: Oxford University Press.

Martin, J. (2018). Profiting from multiple intelligences in the workplace. London: Routledge.

Mayer, R. E. (2002). Multimedia learning. In Psychology of learning and motivation (Vol. 41, pp. 85139). Elsevier.

Nurrahmawati, R. (2016). Peran guru dalam kegiatan pembelajaran bahasa indonesia pada siswa berkesulitan belajar spesifik kelas III di sekolah 
dasar negeri gadingan kulon progo. Widia Ortodidaktika, 5(9), 963-972.

Rakhmawati, R. (2016). Aktivitas Matematika Berbasis Budaya pada Masyarakat Lampung. Al-Jabar: Jurnal Pendidikan Matematika, 7(2), 221-230.

Santika, A. (2019). Peningkatan Hasil Belajar Matematika Menggunakan Metode Tutor Sebaya Siswa Kelas V Di SD Negeri 1 Granting Kabupaten Klaten (Skripsi). Universitas Negeri Yogyakarta, Yogyakarta.

Shideler, L. E., \& Shideler, B. L. (2017). Story based card game. Google Patents.

Siregar, N. R. (2017). Persepsi siswa pada pelajaran matematika: Studi pendahuluan pada siswa yang menyenangi game. Prosiding Temu Ilmiah Nasional X Ikatan Psikologi Perkembangan Indonesia, 1.

Tseng, S.-S., Yang, T.-Y., \& Lu, A.-C. (2019). Developing a Recipe planning Board Game by Design Thinking Approach. Proceedings of the International Conference on Frontiers in Education: Computer Science and Computer Engineering (FECS), 163-168. The Steering
Committee of The World Congress in Computer Science, Computer

Vonny, S., Mawa'Ratu, S., \& Tambunan, J. W. (2019). Penerapan Model Pembelajaran Kooperatif Spontaneous Group Discusion Untuk Meningkatkan Keterampilan Menulis Siswa Dalam Pembelajaran Bahasa Indonesia Kelas III SDN 232 Inpres Dulang. Elementary Journal, 1(2), 33-40.

Wicaksono, A. I., Ardianto, D. T., \& Erandaru, E. (2019). Perancangan Boardgame Augmented Reality Sebagai Media Pembelajaran Bertema Perang Kerajaan Kediri Melawan Tentara Mongol. Jurnal DKV Adiwarna, 1(14), 10.

Wrihatnolo, R. R., \& Dwidjowijoto, R. N. (2007). Manajemen Pemberdayaan: Sebuah Pengantar dan Panduan untuk Pemberdayaan Masyarakat. Jakarta: PT Elex Komputindo.

Yeboah, R., Abonyi, U. K., \& Luguterah, A. W. (2019). Making primary school science education more practical through appropriate interactive instructional resources: A case study of Ghana. Cogent Education, 6(1), 1611033. 